\title{
The Return Song and the Myth of the Founding of the Nation in Vreme na nasilie
}

\author{
By Sybil A. Thornton*
}

Vreme na nasilie (Time of Violence) is a 1988 Bulgarian film based on the 1964 novel Vreme razdelno (Time of Parting) by Anton Donchev (b. 1930). Set in $16^{\text {th }}$-century Bulgaria, the film follows the struggle of a Janissary to convert to Islam the community in which he had been born and the resistance of that community, led by his own family, with harrowing consequences. The article examines the tension between the two narratives informing the structure of the film: that of the $19^{\text {th }}$ century charter myth of the founding of the modern Bulgarian nation, and that of the Greek and Balkan Return Songs. The retrojection of the $19^{\text {th }}$ century and its violence onto the $17^{\text {th }}$ century requires considerable revision of historical realities which would not have supported the plot. More importantly, the structure of the Return Song, as much as it may be ignored or denied because of identification with the Bulgarian "brotherhood" comprehended in the foundation myth, challenges it with the narrative of the betrayal of the birthright inherent in fundamental family relationships.

\section{Introduction: Synopsis of the Film Plot}

Vreme na nasilie (Time of Violence) is a 1988 Bulgarian film based on the 1964 novel Vreme razdelno (Time of Parting) by Anton Donchev (b. 1930). ${ }^{1}$ The time: the $17^{\text {th }}$ century, 1668 to be exact. The historical context: the Ottoman Empire is in a hard-fought campaign to expel the Venetians from Candia (Heraklion), the capital of Crete. The place: a valley in the Rhodope Mountains. The plot: an imperial Janissary (yeni çeri, new army, soldier or troops $^{2}$ ), Karaibrahim, is ordered to convert to Islam the Christian villagers of the place where he was born. They are given ten days to make up their minds. Appeals to sympathetic local Muslim dignitaries fail. Karaibrahim's foster brother Manol uses the time to prepare for a marriage, of which his neighbors do not approve, to Karaibrahim's sister Elitsa, whom he has taken from his own son Momchil. Karaibrahim interrupts the wedding feast, arrests and imprisons Manol and other villagers, and gives the captured women to his men;

\footnotetext{
* Associate Professor, Arizona State University, USA.

1. Vreme na nasilie [Time of Violence], directed by Ludmil Staikov (1988; Boyana Film, 288 min.), bit.ly/1QXt601 and bit.ly/1pqa8Dm; A. Donchev, Time of Parting: A Novel (Vreme razdelno), trans. Marguerite Alexieva (London: Owen, 1967). Although the original title of the film is Vreme na nasilie, the title Vreme razdelno is the title under which the film was shown at the Cannes Film Festival. I will use Time of Violence/Vreme na nasilie to distinguish the film from the original novel. This paper is based on the version on Youtube, which gives no information on its source. Other versions have slightly different subtitles.

2. E. A. Zachariadou, "Janissaries," in The Oxford Dictionary of Byzantium, 3 vols., ed. Alexander P. Kazhdan et al. (New York City: Oxford University Press, 1991), accessed February 20, 2016, bit.ly/1LYeC8J.
} 
the rest of the villagers go into hiding. Stubborn resistance led by Manol is met with torture of the imprisoned villagers one by one. Karaibrahim's brother Goran tries to assassinate him; Karaibrahim kills him in self-defense, but is badly wounded. Manol and the others are massacred when Karaibrahim threatens to kill his younger son Mircho unless he converts. Karaibrahim drops his father Galushko into a pit. Momchil leads a revolt and is seriously wounded; he convinces Mircho to take his head, Karaibrahim's price for releasing Elitsa, who is carrying his child. Mircho kills Karaibrahim; during the melee that follows, in which Karaibrahim's men fall upon the boy and butcher him, Karaibrahim's slave, the Venetian, grabs the girl and they escape.

Converting a novel into a film script requires truncation, excisions, and changes, even when the author of the novel is one of the scriptwriters. Thus, the crucial story of how the Janissary Karaibrahim's foster-brother, Manol, came to the family is left out; this weakens the theme of the villagers as a brotherhood, first formed as resistance to the Ottoman regime when they conspire to keep the baby alive by allowing their wives to nurse this son of a bandit. The stories of fratricide committed by Suleyman Aga, the sultan, and Karaibrahim are truncated or excised, which weakens their force as an exemplary counterpoint to the Bulgarians' brotherhood. The long journeys of the priest Aligorko are left out, and how he came to his realization that the survival of the Bulgarian people was more important than their religion is changed to a mystical vision shot in a famous tourist spot, the famous Prohodna Cave. Karaibrahim's slave is changed from a French nobleman to an Italian (to accommodate an Italian actor); his ineffectual attempt to rape one of the Bulgarian girls is turned into a failed rescue attempt; his care for Elitsa until she is delivered of her child and dies excised. One of the torture scenes is changed into a quartering by tying the victim to four horses. A scene of rape (and murder) is inserted in the flashbacks of Karaibrahim's childhood - an allusion to another film set in seventeenth-century Bulgaria, The Goat Horn (1971) or to the painting The Bulgarian Martyresses (1877). ${ }^{3}$ The book ends with two marriages: that of Sevda, pregnant by either of the brothers Goran and Karaibrahim, to the priest Aligorko, now converted to Islam, and Karaibrahim's sister Elitsa, to the Venetian, a prisoner of war brought from Candia. In the film Karaibraihm throws the widow Sevda to his men; when they are done with her, they throw her lifeless body onto a trash heap. The film ends with the parting of Aligorko and the Venetian and a return of a cross to the priest. The list goes on: the film, then, is neither a literal nor a faithful adaptation of the book.

One of the crucial changes in the film was to restructure the narrative: the novel is a collation of the accounts of two witnesses, the French nobleman who is the Janissary's slave and a priest; on the other hand, the film's point of view looks omniscient, but is in fact not. As will be demonstrated below, the fact that the Janissary is distinguished by flash-backs, a specific film technique, and

3. Kozijat rog [The Goat Hor], directed by Metodi Andonov (1971; Boyana Films and Sofia Film Studios, $105 \mathrm{~min}$.); K. Makovsky, Bulharské mučednice [The Bulgarian Martyresses], 1877, oil on canvas, National Arts Museum of the Republic of Belarus, Minsk. 
the fact that simplifying the novel's plot enhances the structure of the narrative as a traditional Return Song identify the Janissary Karaibrahim as the true, albeit tragic, hero of the film.

\section{The Film and the Myth of the Founding of the Modern Bulgarian Nation}

Both book and film were produced against the political background of the forcible cultural assimilation of Bulgarian-speaking Muslims and of Bulgarian Turks (and Roma as well), which culminated in the massive exodus of over 350,000 Bulgarian Turks into Turkey between June and August, 1989. ${ }^{4}$ The facts that the Bulgarian government subsidized the production of the film and appointed its head of the Bulgarian Cinematography Corporation, Lyudmil [Ludmil] Staikov, ${ }^{5}$ to direct the film indicate that the film was meant to legitimate contemporary state policy--propaganda." ${ }^{6}$ The film was Bulgaria's official entry for the 1988 Cannes Film Festival. ${ }^{7}$ School children were taken in groups to see the film. ${ }^{8}$

The film is set in the Rhodope Mountains in the south and west of the country, which borders on Greece. At issue is a convenient explanation for the high concentration of Bulgarian-speaking Muslims in that area; the goal was to convince Muslims that they had originally been Bulgarian and Christian and forcibly converted to Islam in the past by the Ottoman Turks, who ruled

4. A. Eminov, Turkish and other Muslim Minorities in Bulgaria (New York: Routledge, 1997), 97, citing Darina Vaslileva, "Bulgarian Turkish Emigration and Return," International Migration Review 26, no. 2 (1992): 348, for a figure close to 370,000 and Helsinki Watch, The Expulsion of the Bulgarian Turks (New York: Human Rights Watch, 1989), for the expulsion in general.

5. "Appointed artistic manager of the Mladost (Youth) unit at Boyana Studios, where he specialized in historical chronicles in a thriller context - (sic) Dopălnenie kăm zakona za zaštita na dăržavata Amendment to the Defense of the State Act (1976) and Iljuzija/Illusion (1980) - (sic) Staikov crowned these state-supported achievements with the three-part Khan Asparukh (Han Asparuh) (1981), the cornerstone production for the 1,300th anniversary of the Bulgarian state and the most expensive production in Bulgarian film history. ... In 1987, Staikov was appointed head of the Bulgarian Cinematography Corporation, a position he held until 1991. Despite official duties in the Ministry of Culture, he still found time to direct his heavily nationalistic Vreme na nasilie /Time of Violence (1988), about a clash in a village between Turks and Bulgars during Ottoman rule." Richard Taylor, Nancy Wood, Julian Graffy, and Dina Iordanova, The BFI Companion to Eastern European and Russian Cinema (London: British Film Institute, 2008), 230-231.

6. For an explicit assertion of the film as propaganda for the assimilation program, see Taylor et al., The BFI Companion to Eastern European and Russian Cinema (London: British Film Institute, 2008), 41.

7. It was screened as one of the films in Un Certain Regard. "Vreme Razdelno," Festival de Cannes official website, accessed February 24, 2016, bit.ly/1TY7e3S.

8. Kapka Kassabova, Street without a Name: Childhood and Other Misadventures (New York: Skyhodrse Publishing, 2009), 113. "In the few cases I know of students in the lower grades who did see the film through organized school visits, the children were supposed to see the film as a literal illustration, a kind of fictional documentary." M. Todorova, "Conversion to Islam as a Trope in Bulgarian Historiography, Fiction, and Film," Eurozine (November 4, 2003), accessed February 24, 2016, http://bit.ly/1QpVjcG. 
Bulgaria directly from about 1393 to 1878 . This was an "old saw" that had its origins in the Bulgarian National Revival, which went back to the eighteenth century. ${ }^{9}$ The story takes place in a valley called Elindenya. There is no valley in Bulgaria (or Macedonia) called Elindenya. The name is fictional. What is interesting, however, is how much it sounds like "Ilinden." There are villages and municipalities called Ilinden in both Macedonia and Bulgaria. Ilinden is the feast day of the prophet Elijah, July 20 in the Julian calendar, August 2 in the Gregorian. But, first and foremost, it is the Ilinden Uprising of August 2, 1903: the goals were to provoke interference from the western powers, to prevent the wholesale partition of Macedonia, to preserve its Bulgarian and Christian identity, and to achieve political autonomy within the Ottoman Empire (the next-best-thing to independence). The uprising, connected with another in Thrace, was put down by a typical coalition of Ottoman army and local bashi bazouk (or irregulars) in about two months. The reprisal was savage and thousands of ethnic Bulgarians fled to Bulgaria. ${ }^{10}$

Therefore, the background of this film is not the seventeenth century but Bulgaria's emergence as an independent nation in the nineteenth and early twentieth century as the multi-ethnic, multi-lingual, and multi-confessional Ottoman Empire crumbled under external pressure from Russia and the great western powers and from internal pressure of nationalists, terrorists, and assassins. The complexity of the situation will not be given in this "official version": for justifying the creation of Bulgaria as an independent state, for creating Bulgarians' identity as victims of the Ottomans (where incidents of the nineteenth century are transposed onto the seventeenth century), and for justifying contemporary state policy, we are presented with the modern myth of "the Ottoman yoke" and its theme of forcible conversion through the rape of women and the torture of men.

\section{The Meaning of "Myth" as "the Official Version"}

Like Gone with the Wind, ${ }^{11}$ Vreme na nasilie is a ripping good yarn informed by a myth. In Gone with the Wind, the myth is the Fall from Paradise represented as the Fall of the Old South and the Fall of Southern Womanhood (represented by the heroine, Scarlett O'Hara). In the case of Vreme na nasilie it is the myth of the foundation of the modern Bulgarian state.

9. The monk Paisyi of Hilandar Monastery (on Mount Athos), who wrote the History of the Bulgarian Slavs in 1762, is considered to be the founder of Bulgarian ethnic and national consciousness, although the national revival period did not actually begin until the 19th century.

10. R.J. Crampton, A Concise History of Bulgaria 2nd edition (London and New York: Cambridge University Press, 2005), 126-128 and Encyclopadia Britannica Online, s. v. "Ilinden Uprising," accessed June 06, 2012, bit.ly/1LEdPz2.

11. M. Mitchell, Gone With the Wind (New York: Avon Books, 1936). 
What is a myth? In Homeric epics myth (mythos) refers to the words spoken by those in power, ${ }^{12}$ the voice of authority or, as narrative, the official version. For anthropologists, myth is a narrative of the origins of something (aetiology), usually with a function of persuading the audience that the present is the legitimate outcome of the past, a charter of possession, power, position, and prestige for those controlling the narrative - again, the official version. ${ }^{13}$

What some anthropologists underscore is the function of myth in the creation of social cohesion: identity. ${ }^{14}$ Communities, great and small, are created by distinctive and over-lapping forms of communication: language, gestures, music, dance, food, dress, housing, tools, utensils, decorative patterns, for example, and, of course, myth, which explains how everything began and prefigures everything that will be done after. ${ }^{15}$ For the romantic nationalists since the eighteenth century, myth has been the original voice of a people as defined by geography, language, and culture. ${ }^{16}$

12. ". . .[M]ythos is always a speech of power, performed at length, in public, by one in a position of authority. Normally, a mythos forces assent from those to whom it is addressed, and only those equal in status to the speaker are free to contest such a proclamation." B. Lincoln, Theorizing Myth: Narrative, Ideology, and Scholarship (Chicago and London: The University of Chicago Press, 1999), 17, citing R. Martin, The Language of Heroes: Speech and Performance in the Iliad (Cornell, NY: Cornell University Press, 1989).

13. "Myth fulfills in primitive culture an indispensable function: it expresses, enhances, and codifies belief; it safeguards and enforces morality; it vouches for the efficiency of ritual and contains practical rules for the guidance of man. Myth is thus a vital ingredient of human civilization; it is not an idle tale, but a hard-worked active force... a pragmatic charter of primitive faith and moral wisdom." B. Malinowski, "Myth in Primitive Psychology," in Malinowski and the Work of Myth, ed. I. Strenski (Princeton: Princeton University Press), 82, cited in A. Von Hendy, The Modern Construction of Myth (Bloomington, IN: Indiana University Press, 2002), 208. Malinowski also goes on to say that "myth cannot be sober, dispassionate history, since it is always made ad hoc to fulfill a certain sociological function, to glorify a certain group, or to justify an anomalous status." Bronislaw Malinowski, "Myth in Primitive Psychology," 108 cited in Andrew Von Hendy, The Modern Construction of Myth (Bloomington, IN: Indiana University Press, 2002), 215. This point is elaborated by Raymond Firth and Edmund Leach. On Malinowski, Lincoln notes, "Stressing the connection of text to context within the (ethnographic) present, he theorized myth as a form of 'social charter,' the details of which establish and legitimate the most important aspects of culture." Ibid., 72.

14. Of anthropologists in England and France (Tylor, Lang, Robertson Smith, Frazer, Durkheim, Mauss, and van Gennep), Lincoln notes that they "worked out a radically different model of myth from that of the comparative mythologists. Having come to see myths as primarily an oral, and only secondarily a textual, phenomenon, they studied them in connection with ritual performances and patterns of social organization. . ." B. Lincoln, Theorizing Myth: Narrative, Ideology, and Scholarship (Chicago and London: The University of Chicago Press, 1999), 70.

15. On Jacob Gottfried Herder's Ideen zur Philosophie der Geschichte der Menschheit (1784-91), Lincoln notes, "Myths are thus a discourse of differentiation: the distinctive stories Volker develop as they separate from one another, through which they recall and reproduce their distinctive features." Ibid., 54.

16. Ibid., 210. For a discussion of Herder's concept of the "three factors [that] contribute to the formation of Volker[,]" climate (land), language, and "the development process through which groups acquire their cultural identity and individuals acquire identity as members of these groups[,]" see Lincoln, Ibid., 53. "Here, the big story is the emergence of nationalism, particularly in its relation to romanticism and the quest for a language and a set of stories on which the emergent nation-state could be founded. Toward this end, vernaculars displaced the 
A critical element of the myth, and a focus of the original novel, is the concept of "brotherhood." Ilieva describes the creation of the Bulgarian concept of brotherhood as follows:

It is difficult to pinpoint an exact moment when the idea of the Bulgarian nation as a brotherhood come into shape and took a hold of the popular imagination. Most likely, it was coincidental with the establishment of the concept of the nation itself during the national revival, the second half of the 19th century. The participants of the 1876 April uprising addressed each other with "bratiia." It also related to the popular idea of Slavic fraternity as the peasant term for the Russian soldiers coming to fight the Turkish Empire was "bratushki." The notion of the nation as brotherhood had become a commonplace by the 1920s. ...By the time Donchev was writing in the 1960s, the national brotherhood was a well-established trope. ${ }^{17}$

The modern brotherhood, created in the face of appalling violence (such as the "Bulgarian horrors" of 1875-76), "is consolidated and becomes a meaningful category of self precisely in the traumatic confrontation with the foreign power. Its cohesive force, therefore, is resistance." ${ }^{18}$ Here should be meant Bulgarian resistance to the Ottoman Empire and its forces during the April Uprising of 1875-76 and the Ilinden Uprising of 1903. Now, technically only those who participated in the modern, historical resistance to the Ottoman Empire, the catalyst to the creation of the nation state, should be considered members of the brotherhood. However, as can be seen in this film and others (like The Goat Horn) the violence and the resistance to it are seen as going back to the seventeenth century (if not earlier). The novel Time of Parting is explicit about the creation of a brotherhood of resistance to Ottoman forcible conversion under the pitiless leadership of Manol, who forces the shepherds to undergo torture rather than convert. Thus, a myth of resistance is created and a myth of brotherhood with the retrojection of the nineteenth century onto the seventeenth.

As a narrative defining those who belong to the brotherhood, the myth is also the concomitant narrative imposed on those people from whom the brotherhood attempts to differentiate itself. Myth, then, even in the modern period, is developed as a charter for the foundation of a community, in this case a nation. Where myth is the charter for the nation, it can be, at the same time, the charter for politically charged racism, ethnocentrism, xenophobia, ethnic cleansing, and genocide. ${ }^{19}$ It is no coincidence that in this film the myth of the

international languages of church and court, while myths (and to a lesser extent, folk songs) were constituted as the authentic, primordial voice of the Volk." Ibid., p. x.

17. A. Emilova Ilieva, "Romulus's Nations: Myths of Brotherhood and fratricide in Rusian and South Slavic National Narratives" (PhD diss., Northwestern University, 2005), 165.

18. Ibid., 155.

19. For a discussion of how "Nietzsche used mythic narratives not just to stereotype peoples but also to erect a discriminatory structure of interlocking binary oppositions that conflated categories or race, gender, religion and morality[,]" see B. Lincoln, Theorizing Myth: 
founding of the state is invoked to legitimate a misconceived national policy. It is also no coincidence that the myth excludes certain Bulgarians from the brotherhood, including Muslims of all stripes, and including the main protagonist, the Janissary Karaibrahim, a natural brother.

\section{The Janissary as Synecdoche of the Myth of Forcible Conversion to Islam}

Popular reception of the film's participation in the myth of the founding of the nation is articulated in one description of the film:

Based on eyewitness written accounts. In the 17 th century, a Bulgarian Christian region is selected by the Ottoman rulers to serve as an example of conversion to Islam. A Janissary who was kidnapped from the village as a boy now serving the Ottoman sultan is sent to force the reluctant inhabitants to convert. The Bulgarian christians [sic] have to chose between physical annihilation and losing their spiritual identity. Ultimately torture, violence, and rebellion break out. Based on real events and the novel "Time of Parting" [sic] (Vreme Razdelno [sic]) by Anton Donchev.

The novel is based on two individual eyewitness written accounts [sic] by the priest Aligorko and the Venetian. The resulting text is a translation of the original French and Old Bulgarian (Old Church Slavonic) texts. All names, characters and events appear in the original manuscripts. ${ }^{20}$

What we find here is a summary of the received knowledge about the basis of the film's narrative as well as of the film's role in transmitting and developing the myth of the founding of the nation. ${ }^{21}$ Four themes are represented here. First is the belief in the historical authenticity of the events and of the sources on which the narrative is based (the sources have long been discredited as forgeries ${ }^{22}$ ). Second is the mistaken identification of the fictional eye-witness accounts of the novel with historical sources. Third is the theme or trope of "forcible conversion (which has already been dealt with exhaustively

Narrative, Ideology, and Scholarship (Chicago and London: The University of Chicago Press, 1999), 65. See also Ibid., 71 for "Table 3.1 Organizing Structures in Philological and Anthropological Approaches to Myth toward the end (sic) of the Nineteenth Century."

20. Uploaded by zarni000 on Oct 4, 2009 (accessed Jan. 25, 2012).

21. Other themes include the "tragic consequences of the devşirme (the returning son executes his father); brave resistance by the Bulgarians, and themes of martyrdom and sacrifice." Charles Hamilton Argo, "Ottoman Political Spectacle: Reconsidering the Devsirme in the Ottoman Balkans, 1400-1700" (Ph.D. diss., University of Arkansas, 2005), 227. Argo discusses the themes of historiography as well as those in Vreme razdelno.

22. M. Todorova, "Conversion to Islam as a Trope in Bulgarian Historiography, Fiction, and Film," Eurozine (November 4, 2003). 
and needs no further comment" ${ }^{23}$ ). Fourth, and most important, is that of representation of the Janissary, paradoxically, tragically, and ironically, as both victim and perpetrator of the horrors of the "Ottoman yoke."

This last theme is set up at the very beginning of the film: the film's opening shot of a map of Bulgaria fades out and there is a cut to medium closeup from behind of Karaibrahim attending to his reins. He stops and bows his head. Then there is a cut to the Grand Vizier, ${ }^{24}$ shot from behind a line of Janissaries and the camera follows him from left to right across the screen. A cut back to Karaibrahim with his head bowed; a voice speaks over the shot: "I fear not that there are enemies of the padishah still walking the Earth." There is a cut to the face of the Grand Vizier: "We will crush them just [as] we crushed the [Romanians], Bosniaks, Bulgarians, Serbs. I dread not that many of his subjects still worship the Cross. Only when a single faith binds us, only when all fly the holy banner of the Prophet, only then will we become invincible. If we fail in this, the world will never belong to us." There is a cut back to Karaibrahim, who turns a sad, almost agonized face to the camera. He is to be the perpetrator of "the Ottoman yoke" and "forcible conversion," but he hardly suggests that he is looking forward to the mission.

The Janissary is the vehicle for several myths. For example, although Karaibrahim is not in the uniform of a Janissary (blue coat and a headdress like a stiff, white sock standing upright on the head and folded sharply to hang behind) and is mounted (Janissaries are infantry units except for mounted troops assigned to the sultan), the flashbacks make clear that he is one of those Christian boys recruited through the devshirme, the levy of boys on Christian communities in the Ottoman Empire, perhaps the one in $1638 .{ }^{25}$ By then, enrolment had long been extended to Muslims - especially to the sons of Janissaries - who clamored for the right to enter the only regularly paid army this side of the Urals and the chance to rise to the position even of Commander of the Janisaries - if not higher. Karaibrahim would have been one of the very last of the Christian recruits of a regularly scheduled devshirme. ${ }^{26}$

Karaibrahim's recruitment and training are depicted in a series of flashbacks, which begin with scenes of his boyhood and end with shots of his screaming mother clutching him and his foster-brother Manol to herself, of a Janissary with a scar under his right eye shaking a whip at the camera, of the face of his father watching helplessly, of himself being dragged away to a line

23. Ibid.

24. This is Köprülü Fazıl Ahmed Pasha (1635-1676), whose father Mehmed had been the previous Grand Vizier. An Albanian, he had been recruited through the devshirme system. He himself led the siege against Candia and brought it to a successful end.

25. The date is suggested by the scene in the novel where Manol exacts three promises from his younger son and he explains that, thirty years before, Old Galushko had given his son Strahin to the Janissaries and saved him.

26. Devshirme declined in number as demands for the sons of Janissaries and Muslims to be admitted were made. However, sporadic levies were made until 1705. V.L. Ménage, "Devshirme," Encyclopaedia of Islam, Second Edition, available at Brill Online (2012), accessed June 8, 2012. See also G.A. Russell, "Physicians at the Ottoman Court," Medical History 34, no. 3 (1990): 243-267, accessed June 8, 2012, 1.usa.gov/1LWibl7. 
of other boys and Janissaries, and of his mother running up a hill stretching out a bag of food, of himself in the school with other boys, putting a yellow hat on his shaved head (a sign perhaps both of conversion to Islam and cadet status), a boy running and falling as a Janissary screams and flicks a whip, of the face of his mother clutching the bag. ${ }^{27}$

Karaibrahim's flashbacks then represent the devshirme as a savagery inflicted on the Bulgarian peasantry. Other scenes reinforce this. Fear of losing their boys drives the villagers to send them scurrying into the forest and hills to hide. However, in actuality, this was not possible. The procedure was to send a detachment of Janissaries to collect the boys once every several years. All villages would be ordered to bring their boys of twelve to nineteen or thereabouts to the nearest town on a specific day. The men and the boys would go down to the town, whose own boys (spoiled by city life) were excluded from recruitment; there they would find the local Greek Orthodox priest (the second yoke under which the Bulgarians labored) with the baptism roll and a Janissary colonel. They would be examined for health and intelligence; one boy 15-20 years of age from forty households would be taken unless an only son or son of a widow. The boys would be dressed in red and marched to Erdine or Istanbul, where they were examined, circumcised, and assigned to palace schools or Anatolian farms and estates to learn Turkish. The devshirme was a cold, calculating and ritualized demonstration of the Sultan's power; ${ }^{28}$ but, it was not meant to strip the fields of their workers. The devshirme was a form of taxation, not the terrifying rape or kidnapping presented in the film. History, then, has been distorted for the sake of the myth of the founding of the nation.

As a character, Karaibrahim is the vehicle for yet another myth about Janissaries, that of "fanatically faithful soldiers of the sultan" articulated by titles in the first shot of the film. ${ }^{29}$ That statement, however, is challenged in the scene where Karaibrahim and the ruler of the valley, Suleyman Aga, meet formally for the first time. As they feint, thrust, and parry over coffee, on which the former Grand Vizier had placed a ban which the present Grand Vizier, his son, had subsequently lifted, Suleyman Aga, says pointedly, "A day doesn't go by that I don't think about the grand vizier. Let me show you the sword that he gave me at Belgrade, when the janissaries revolted." Looking straight at Karaibrahim, he continues, "I killed the first one to raise a hand against him." A sword of gold is handed to Suleyman Agha, which he passes to Karaibrahim. Holding it both hands, Karaibrahim examines it politely, if perfunctorily, and replies as he hands back the sword, "And you are still alive?

27. The trauma of losing his mother is a theme throughout the film. Elitsa is saved from rape by Karaibrahim when a flashback to his mother causes him to recognize her as his sister. The first words he speaks to his father are to ask after his mother.

28. See C.H. Argo, "Ottoman Political Spectacle: Reconsidering the Devsirme in the Ottoman Balkans, 1400-1700" (Ph.D. diss., University of Arkansas, 2005).

29. For a discussion of the loyal Janissary, see L. A. Coser, "The Alien as a Servant of Power: Court Jews and Christian Renegades,"American Sociological Review 37, no. 5, (1972): 580, citing G. Simmel, The Sociology of Georg Simmel, tr. and ed. Kurt H. Wolf (Mankato, Minnesota: The Free Press, 1950), 383. 
Where were the comrades of that janissary?" "They were with him. I killed them, too."

This is a tense exchange between a Janissary in disguise and a local leader who has killed Janissaries to protect the Grand Vizier, either the present one or his late father. Both had been in and out of Belgrade in their campaigns on the northern frontier, but I can find no evidence of an assassination plot carried out or suppressed by either in Belgrade itself. However, outrages committed by rogue Janissaries in Serbia eventually led to the Serbian Revolt of 1804. Nevertheless, with the first revolt in 1449 to demand a raise in pay, the Janissaries began to gain increasing control over the palace, culminating in the execution of Osman II (1604-1622). In 1632, in a failed revolt against Murad IV (1612-1640), they killed his Grand Vizier Hafiz Ahmed Pasha (b. 1564, son of a Bulgarian Muslim). By this time, the Janissaries were hardly deserving of being called "loyal" to the sultans or their servants. Again, history is distorted in order to support the myth.

The focus of the film is on the Janissary Karaibrahim. This opening scene of the film, as opposed to the novel's collation of the accounts of two eyewitnesses, makes Karaibrahim the true, but tragic, "hero" of this narrative. Only Karaibrahim is characterized by flash-backs, as in the flash-back to the Grand Vizier, a specific film technique which violates the continuity of time and space and codes the entrée into the protagonist's mind. These come again in the next scene in which Karaibrahim and his detachment make their way through the mountains, the second half of which is intercut with scenes of Karaibrahim's idyllic boyhood, ${ }^{30}$ recruitment and training; the last is of his mother. Karaibrahim serves as a vehicle of conflicting myths about the "Ottoman yoke" revolving around the Janissaries: the cruelty of the system by which they were recruited and trained, the cruelties inflicted by them on the Christian peoples of the Balkans, their fanatical devotion to the sultan, and even their nostalgic devotion to their mothers.

\section{Karaibrahim as the Hero of the Return Song}

Despite the fact that Karaibrahim is the villain of the piece, he is also the hero. This is accomplished through the structure of his narrative as a Return Song, ${ }^{31}$ a genre known to us in texts such as the ancient-Greek Odyssey and preserved in the oral epic traditions of the Balkans. For example, Odysseus has

30. These are more than merely reminiscent of scenes of a pastoral boyhood in the 1958 Soviet film, Mameluqi (Mameluk), another story of abduction and service as a slave-soldier to an Islamic power, based on the eponymous novel by Kondratii Tatarishvili (Uiarago, 18721929). Mameluqi [Mameluk], Directed by Davit Rondeli (1958: Grusia Film/Qartuli Pilmi, 97 min.), http://bit.ly/1SFhr5B (uploaded by MrGeorgian2010 on Jun 6, 2011) in Georgian and in Russian as Mamlyuk.1958, http://bit.ly/1UkIjrm, bit.ly/228imhw.

31. The genre was identified as such by Albert Lord. As a genre, as John Miles Foley has noted, it is "a pan-Balkan (and very probably Indo-European) story form" J. Miles Foley, "Tradition and the Collective Talent: Oral Epic, Textual Meaning, and Receptionalist Theory," Cultural Anthropology 1, no. 2 (1986): 203, accessed September 25, 2011, bit.ly/1LWjAYY. 
been in the war against Troy. He journeys back, although his return takes him years due to captivity by Calypso and Circe, through the intervention of Athena. He finds his wife Penelope forced to give entertainment to her unwelcome suitors and massacres them. Then, after testing her with a riddle, he resumes his married life with Penelope. John Miles Foley (after Lord) analyzes the Return Song as follows: Absence-Devastation [captivity]-Return [release through intervention of sympathetic female]-Retribution [disguise, recognition by father, defeat of suitors, and testing the wife]-Wedding. ${ }^{32}$ However, not every hero is as successful as Odysseus: Agamemnon, for example, returns from Troy to be murdered by his wife Clytemnestra, who has taken up with (married) his cousin Aegisthis because Agamemnon had sacrificed their daughter Iphigenia to the goddess Artemis so that the army could depart for Troy. The Return Song is a flexible pattern of units, not a strict plot line. Nevertheless, this five-part sequence also structures the SerboCroatian epic and the Balkan moslem epics, as well, even if as fragmented, scattered elements reintegrated into an original narrative.

In its more recent, Balkan form, the Return Song is much briefer: "a hero returns home and regains his former position in his marriage and family." ${ }^{33} \mathrm{In}$ Bulgaria, the Return Song is of the sub-type "Soldier (Christian)": ${ }^{34}$

...the hero departs to the army (becoming a soldier) soon after his marriage, usually instructing his wife that if he has not returned by a certain number of years, she may remarry. Shortly before or just when the designated time has elapsed, his wife weds again. In many versions, the hero's father, despondent over his daughter-in-law's

remarriage, deserts the wedding party and goes to his vineyard...Just then the soldier - the hero who remains incognito - arrives there and learns from his father that his wife is about to remarry. He joins the wedding festivities and discloses his identity. His wife responds either by joyfully remarrying him or rejecting him to marry her new love, in which case the hero kills both her and the rival groom. ${ }^{35}$

32. Ibid., 206. "Most basically, the pattern presents the saga of a hero called off to war who is absent and held captive for an extended period of time, and who then overcomes numerous difficulties on his way back home, where-always in impenetrable disguise and cleverly testing his relatives' and allies' loyalty-he eventually conquers the suitors pursuing his wife or fiancée by initially defeating them in athletic contests and then (if necessary) slaughtering them. The story may, however, follow an alternate route that we might understand as the Agamemnon-Clytaemnestra option: according to this second option the wife or fiancée proves unfaithful, having taken a substitute mate, and the tale tracks off in another direction. Worldwide, the Hollywood ending and the Agamemnon-Clytaemnestra option are about equally common." J. Miles Foley, "South Slavic Oral Epic and the Homeric Question," Acta Poetica 26, no. 1-2 (2005), 61-62, accessed September 21, 2011, http://bit.ly/1pkb50j.

33. M. Beissinger, "Gender and Power in the Balkan Return Song," The Slavic and East European Journal 45, no. 3 (2001): 405, accessed September 12, 2011, http://bit.ly/21mdG5e.

34. Ibid., 406.

35. Ibid., 407. Beissinger relates real-life experiences throughout the modern period in the Balkans which parallel these stories. 
While Foley describes the five-part structure in terms of its function, I would describe it in terms of variations of its performance of several scenes in no particular order and featuring one or more characters: war, captivity, return, massacre, and marriage. Let me now go through the structural units of the Return Song to see how they play out in the film Vreme na nasilie. (This procedure has been referred to disparagingly as "motif spotting;" bear with me. ${ }^{36}$ )

The first unit is War. The war for the Odyssey is of course the ten-year war with Troy. The war in which Karaibrahim serves is the siege of Candia (modern Heraklion on the island of Crete) was a campaign of the sixth war between the Ottoman and Venetian empires from 1648 to 1669. This is represented in the film by the opening sequence: a shot of an old map quickly fades in and zooms into the words "Rhodope" under which a red line appears; titles appear [my emendation of translation into English]:

The year is 1668. The Ottoman Empire has long since conquered South-Eastern Europe, but the Holy War for the total domination of Islam continues. The battle rages on for Candia (Crete). A Janissary detachment is sent to the Rhodopes - a Bulgarian mountain of great strategic importance. [They] are young Christian boys, separated by force from their parents, raised with unimaginable cruelty and transformed into fanatically faithful soldiers of the sultan.

Karaibrahim brings the battle for Candia to Elindenya. He explains the significance of his mission to Suleyman Aga, the ruler of the area. Dressed in fresh clothes (gold lamé turban wound round a fez, over shirt, and trousers, white shirt and dark short-sleeved overcoat), seated on a divan, he inspects and returns a sword in a gold scabbard given the Aga by the Grand Vizier, and, looking Suleyman in the eye, says:

The grand vizier is outside the walls of Candia in deadly combat with the infidels. The Battle for the Rhodopes is a battle for Candia. The battle for Candia is a battle for the future of the empire. Suleyman Aga, if we are to win, this mountain must forget the Bulgarian name. When he sent me here, the grand vizier told me: "The Rhodopes is a fortress and when you leave and look back all you must see is minarets and not even one cross. Only then will that fortress be ours. And the Janissaries' aga said..." [Suleyman Aga interrupts to show him silver pistols given him by the Janissaries' aga.]

As for the premise that the Rhodope mountains in Bulgaria had any strategic value in its war against the Venetians, "...[t]he Rhodope Mountain was not included in the strategic plans of the Ottomans and there was no reason

36. M. J. Koven, Film, Folklore, and Urban Legends (Plymouth, U.K.: Scarecrow Press, 2008), 3, 79 . 
for any elite military units, such as Janissaries, to be stationed there." ${ }^{37}$ Imperial Janissaries were posted to the large-scale fortresses on the borders, in Istanbul, and to the navy.

The second unit is Captivity. This is represented by Karaibrahim's recruitment and training as a Janissary, as discussed above. Captivity is a theme replicated in the film: the captivity of Karaibrahim's slave, the Venetian, captured at Candia; the captivity in the konak of the notables among the shepherds; and even the captivity of Elitsa by her brother Karaibrahim, who initially takes her to rape her. However, since the film's Return Song is focused on Karaibrahim, so is the theme of captivity.

The third unit is the Return. Under orders from the Grand Vizier, the Janissary makes a return journey to the Rhodope Mountains, where he was born. This is a long passage at the beginning of the film under the credits. His journey, like that of Odysseus, is also difficult. He must climb tall mountains and his train is hit by falling rocks.

The Return is characterized by several narrative units (tropes, themes, or scenes) disguise, recognition, and deception ${ }^{38}$ (after all, Odysseus was famous for his wile - it was he who thought of the Trojan horse).

First, Karaibrahim is in disguise; he is not in the uniform of the Janissaries. When we first see him, he is wearing a dark-blue and grey striped turban wound round a fez (tall cap), a close-fitting coat with short sleeves over pants and a long-sleeved, close-fitting shirt, a knife stuck into broad brown sash and long sword hanging from a baldric. The flashback recounting his recruitment shows what the uniform of a Janissary should look like: a tube of thick, white material secured with a band around the forehead that stands straight up until folded to hang over the shoulders, a dark blue coat to the knees, leather belt and baldric. Karaibrahim leads a unit of mounted men, which Manol identifies to Grandpa Kralyu as "Turkish cavalry;" he tells Old Galushko, his foster father, "I don't think there are any of ours there. They were all sipahis, I didn't see any Janissaries." Sipahis were Muslims, armed knights serving the sultanate, which exchanged land for military service; Christian boys recruited by the levy served in the Janissaries (or the bureaucracy). Karaibrahim was not recognized as a Janissary, nor as Strahin, the boy who had been taken away to become one. Even though Karaibrahim was close enough to Manol to knock off his fur hat with a whip, Manol did not recognize him; ${ }^{39}$ in turn, when he heard the priest Aligarko address Manol by his name, Karaibrahim's face betrayed nothing, certainly nothing in the way of recognition. Because Karaibrahim's true identity is not known, one of his brothers, Goran, perhaps too young ever to have known him, attempts to kill him.

37. E. Radushev, "'Peasant Janissaries'?"' Journal of Social History 42, no. 2 (2008), 454, accessed September 27, 2011, http://bit.ly/1XhJS8Q.

38. For deception in the Return Song, see M. Beissinger, "Gender and Power in the Balkan Return Song," The Slavic and East European Journal 45, no. 3 (2001): 409-410.

39. The rest of the men are not dressed as spahis, but as nineteenth-century mercenaries, the bashi-bazouk: the costumes are regional and "civilian": turban or turban wound around a fez, jacket, wide pants, broad sash and any number of weapons stuck into them. 
Paired with disguise is recognition. Following the model of the Odyssey version of the Return Song, Karaibrahim's father Old Galushko does recognize him: twice as he is engaged with his work in the mill, he turns his head to see Karaibrahim on a far distant hill just as he turns about and gallops off; the second time he drops to the stairs in shock. But Old Galushko tells no one until he, along with other villagers, is dragged in to identify the corpse of the man who tried to kill Karaibrahim; when in the struggle Goran himself was stabbed, he deliberately dropped with his face into the fire to disfigure it. Karaibrahim refuses to identify the attacker, although he knows who he is: Goran had declared himself to be "Goran, Galushko's son" as he drew his knife.

Recognition is not merely a matter of knowledge, but of acknowledgement. The villagers pretend not to know the identity of the dead man lying on the ground inside the konak. But when Galushko, accompanied by two guards, is brought into the konak and sees the mutilated man stretched out on the ground, he bends over to pull together the edges of his jacket and smooth them down; he straightens up and says quietly, "Goran. My son." Manol protests that he is mad. But Galushko insists, "Manol, it's him. Why do you hide his name? Let the people know what he has done. Let the mountain remember him. He is Goran. My son!"

The fourth unit is the Wedding. This is the result of another act of deception is performed on Karaibrahim's part. When the village elders first come to see him in the konak, he tells them outright, "I give you ten days, starting from today. If you don't come [by] the tenth day to accept the true religion, my hands will be [untied]." However, on the seventh day Karaibrahim interrupts the wedding celebrations of his blood-brother Manol and his sister Elitsa and arrests everyone who cannot get away. He gathers his men, forces them to carry their shoes as they creep through the woods, and surrounds the wedding party. As the end of the dance line passes, Karaibrahim is revealed behind it; he pulls out his pistol, steadies it on his left wrist, aims and shoots a hole into a bagpipe; he throws away the pistol, then walks straight toward Manol and Elitsa over a banquet laid on the ground--over white cloths, bread, olives, chicken, cheese, yoghurt, and wine that Manol and Elitsa have worked so hard to prepare in such a short time. In the fight, he even threatens Elitsa with a knife to force Manol to submit to arrest. Manol asks, "Why are you here? There are three more days left, out of the ten you gave us." Karaibrahim answers, "That's right. But you will spend them in the [konak]. The days were for consideration, not for wedding celebrations." 40

Massacre is the fifth and final unit of the Return Song.; scenes of massacre, rape and torture are spread throughout the film. Karaibrahim coldly shoots a slave fixing a roof to announce his arrival at the konak (residence and

40. In the film, the narrative is truncated: there is no marriage as such. Elitsa is released by Karaibrahim along with the priest Aligorko; we next see her eating honey when Momchil enters the house and they stare at each other, she with tears in her eyes, he with suspicion. We only learn that they have had relations when the priest Aligorko, now converted and wearing a turban, enters the rebel hideout and announces to Momchil, wounded, prone, and attended by a comrade, "Karaibrahim sent me to tell you that in three days he's going away. He is to take Elitsa with him. She's with child." 
headquarters). He tortures the villagers to force them to convert; his men rape their daughters and granddaughters in a night-long orgy of ripped blouses and thrashing thighs. The remaining imprisoned villagers are massacred. As a last fillip, Karaibrahim invites "the boys to have a walk in the valley," whereupon his men swarm out of the konak, along with all the irregulars, down into the village, and run off with all the peasants' boxes and blankets they can carry, burn the houses, and set afire branches piled at the mouth of a cave in which refugees have taken shelter.

Like Odysseus and Agamemnon, Karaibrahim returns home. Like Odysseus, he slaughters his rivals. Like Agamemnon, he himself is slaughtered. There is no homecoming for the Janissary, even a native son, who tries to come home.

\section{The Myth of the Returning Janissary}

The violence Karaibrahim perpetrates, according to Postema, realizes the fears of Christian villagers that sons made Janissaries might return to do them ill. $^{41}$ The misunderstanding of how devshirme worked is necessary to the film narrative, for it explains the villagers' fear of the return of their sons and gives a reason for Karaibrahim's cruelty to his own family. Manol is terrified that his younger son Mircho might be taken; he tells him,

You know that soldiers came today. They will probably take children as janissaries.

They were here when I was your age. Had they taken me, I would be a janissary now.

...No one is born a janissary, my son. I don't know what they do to the Christian children

after they take them away, but they turn them into beasts. ${ }^{42}$ I won't let that happen with you.

Because of this fear, Manol is prepared to kill Mircho rather than allow him to be taken; he forces Mircho to swear over the remains of his mother to keep one of three promises, should he be taken by the Janissaries: to jump off a bridge, to jump off a cliff, or to allow his father to shoot him in the heart.

Even Karaibrahim uses the threat against Manol's son Momchil, who is the leader of a rebellion against him. The priest Aligorko tells him that Elitsa is pregnant with his child, and that "Karaibrahim says, if it's a boy, he'll make

41. "...[G]iven the rampant fear of the highly symbolic possibility of a janissary son's later retum to murder his genetic father in the boy's former hometown... ." A Postema, "My Son I Will Give - My Myth I Will Not: Lineage and Legendary Identity in Donchev's Time of Parting," Balkanista 22 (2009), 167-180. "Despite the horrors of such separation, there is evidence that children who rose high in the imperial service favoured their native areas." Encyclopadia Britannica Online, s. v. "Balkans," accessed June 06, 2012, http://bit.ly/1P3GnwO.

42. "Beast" is what Manol's son and Karaibrahim's sister Elitsa call Karaibrahim. 
him a Janissary to come back one day to the valley and do to his father what Karaibrahim did to his own."

The fear of the returning Janissary son does not prevent Old Galushko from giving up his own son, Strahin (renamed Karaibrahim), instead of his foster-son Manol. The film suggests in the shot of Galushko's wife screaming and clutching both boys to her that her love for them was equal. But Galushko's choice has terrible consequences. Karaibrahim's mother dies of grief. Galushko is a broken man: "There's nothing more they can take from me," he says of the Ottoman army in the valley." And, yet, the responsibility for his sorrow can be laid at his own feet for giving up his own son instead of the orphan Manol-not that, in historical reality, as demonstrated above, Galushko would have had a choice.

More importantly, abandonment by his father has scarred his son Karaibrahim. He asks Old Galushko, "But you could give me up to be a janissary. Why didn’t you give away Manol?" "Manol wasn’t my son. How could I give him? A man can give away only what is his own." Would Manol have had reason to be as angry with Galushko as Strahin?

Moreover, Strahin's return as Karaibrahim gives Galushko the opportunity to abandon him yet again. He tells the badly wounded Karaibrahim, propped up on a divan, his face as badly scarred by his brother Goran's knife as Goran's face is by the fire he rolled into: "God did not have mercy on me. I lived to see you."... "Did you send him [Goran] to kill me?" "No, my son. But if I had known, I wouldn't have stopped him."

"And so it is. And I will give away my own. And every living thing will scream." Karaibrahim, the abandoned and denied son, is now free to be the Janissary of all their nightmares. He wreaks his vengeance when he casts his father down into the pit where the dogs that turn on sheep are dropped, despite the mullah's protest that the Koran does not condone the parricide even of an infidel father.

The problem is that, even though Strahin has been forgotten, Karaibrahim has never forgotten his family. Despite his orders to convert the villagers of Elindenya, he had hoped to do the best by them. When a Janissary detachment of four hundred is sent to assist him, he goes to his father, imprisoned in a room in the konak, in a rage. "They sent me help! To me! They've decided that I'm unable and that Karahasan (commander of the Janissary regiment) is able. Where he has passed, the people have converted. And I? I stay here and wait! I, Karaibrahim, the first one! The favorite of the janissaries' aga. I do nothing and wait! I wanted to save you. To prevent bloodshed." To Manol he says, "I came with open arms. I wanted to give you the whole valley, so that you might gain power and strength. I wanted to save you, to transform you into normal people." He has been watching his father's mill, but run off when spotted. He has an almost mystical affinity for his own blood. After breaking up the wedding party, imprisoning the chief men of the village, and sending the girls off to be raped, he has the bride Elitsa sent to his room to have his wicked way with her, but he suddenly recognizes who she is: she stands there with a lit brand from the fire to defend herself; he steps forward as the camera moves 
into his face slightly and suddenly he flashes back to a long-distance shot of his mother-Elitsa's mother and his--running up the hill holding out the bag to him. In all the time he keeps her in the same room he sleeps in, he never touches her. ${ }^{43}$

In the novel, blood no longer counts for the villagers, who have accepted Manol as their leader: they saved him when he was a baby, Galushko raised him; he married into the community and won their respect with his tremendous physical and moral strength. According to Postema, Manol belongs to the community and brotherhood, no longer based on a common lineage but on common participation in a legend, ${ }^{44}$ which we can call the myth of the nation by his resistance to the Ottoman Empire. In the film, too, once the boy Strahin is taken away, he is no longer a member of his family or community-especially after his own brother tries to kill him and his last ties to his family are cut. As Manol tells Karaibrahim, "Only the dead fear nothing. Perhaps you don't fear anything because you've already been dead a long time, Strahin. Your roots are dead and you stand dried up." "The last root was cut by you (plural), when my brother tried to stab me." Goran's knife had slashed him from his right temple across the bridge of his nose to the left corner of his mouth. "Look. When I stroke my head, I feel nothing. It is the same in my soul. I have no brothers, no sisters, no people of my own. Nothing." "What kind of brother can a janissary be?" asks Momchil of Elitsa. What kind of son? Only those who are the victims of the Ottoman yoke, only those who sacrifice and are sacrificed for the nation can be sons and brothers.

Like Agamemnon in his Return Song, Karaibrahim returns to challenge a marriage (he breaks up the wedding of his sister) and to death (he is slain by his blood-brother's son). Even more crucially, for the myth of the founding of the nation, Karaibrahim returns to exclusion. Thirty years as a Muslim, a Janissary and experienced soldier, and, apparently, as good as dead to his family had completely stripped Karaibrahim of his previous identity-even though he is repeatedly addressed by his relatives as "Strahin," his boyhood name--and rendered a "beast": not just not one of them, but not even human.

If the myth of the founding of the nation defines who belongs, then the same myth defines who does not. This lesson of the myth should have been considered more seriously. If forced, as the title of the novel Time of Parting (of the ways) suggests, to take sides, society can respond only with radicalism and violence (as in the film title Time of Violence). By his own choice, Galushko abandoned his son; later, he refuses him recognition and

43. This is a theme found in a Bulgarian folksong, "The Janissary and the Fair Dragana," collected and published by the Miladinov brothers in 1861. C. Miladinov and D. Miladinov, Bulgarski Narodni Pesni I Poslovitzi [Bulgarian National Songs and Proverbs], 12, cited in W.R. Morfill, M.A., Slavonic Literature (London: Society for Promoting Christian Knowledge, 1883), 125, 137-139 for Morfill's translation.

44. A. Postema, "My Son I Will Give - My Myth I Will Not: Lineage and Legendary Identity in Donchev's Time of Parting," Balkanista 22 (2009), 167 and 179. The idea of the myth of the nation rests in the context of the brutal separation of Bulgarian Christians and Bulgarian Muslims and the even brutal qualities of the men, like Manol and Karaibrahim, necessary to carry it out. 
acknowledgment. Strahin/Karaibrahim responds with rage, hardens the lines between himself and his family, kills his brother, and drops his father into the pit. The actor portraying Strahin/Karaibrahim, Iossif Surchadzhiev, was probably most cognizant of the real issue in the film when he said, "I was not interested in the villain in Karaibrahim, but in how one becomes a villain." 45

\section{Bibliography}

Argo, C.H. "Ottoman Political Spectacle: Reconsidering the Devsirme in the Ottoman Balkans, 1400-1700." Ph.D. diss., University of Arkansas, 2005.

Beissinger, M. "Gender and Power in the Balkan Return Song," The Slavic and East European Journal 45, no. 3 (2001), 405. Accessed September 12, 2011. http://bit.ly/21mdG5e.

Coser, L. A. "The Alien as a Servant of Power: Court Jews and Christian Renegades. "American Sociological Review 37, no. 5, (1972).

Crampton, R.J. A Concise History of Bulgaria $2^{\text {nd }}$ edition. London and New York: Cambridge University Press, 2005.

Donchev, A. Time of Parting: A Novel (Vreme razdelno). Translated by Marguerite Alexieva. London: Owen, 1967.

Eminov, A. Turkish and other Muslim Minorities in Bulgaria. New York: Routledge, 1997, 97, citing Vaslileva, D. "Bulgarian Turkish Emigration and Return." International Migration Review 26, no. 2 (1992): 342-52.

Eminova Ilieva, A. "Romulus's Nations: Myths of Brotherhood and fratricide in Rusian and South Slavic National Narratives." PhD diss., Northwestern University, 2005.

Encyclopaedia Britannica Online, s. v. "Ilinden Uprising." Accessed June 06, 2012. bit.ly/1LEdPz2.

Encyclopadia Britannica Online, s. v. "Balkans." Accessed June 06, 2012. http://bit.ly/1P3GnwO.

Hartel, J. "Filmfest Offers First Bulgarian Film in U.S." The Seattle Times (Monday, May 22, 1989), C.9.

Helsinki Watch. The Expulsion of the Bulgarian Turks. New York: Human Rights Watch, 1989.

Kassabova, K. Street without a Name: Childhood and Other Misadventures. New York: Skyhodrse Publishing, 009.

Koven, M. J. Film, Folklore, and Urban Legends. Plymouth, U.K.: Scarecrow Press, 2008.

Kozijat rog [The Goat Horn]. Directed by Metodi Andonov (1971, Boyana Films and Sofia Film Studios, $105 \mathrm{~min}$.).

Lincoln, B. Theorizing Myth: Narrative, Ideology, and Scholarship. Chicago and London: The University of Chicago Press, 1999, citing Martin, R. The Language of Heroes: Speech and Performance in the Iliad. Cornell, NY: Cornell University Press, 1989.

Makovsky, K. Bulharské mučednice [The Bulgarian Martyresses], 1877, oil on canvas, National Arts Museum of the Republic of Belarus, Minsk.

45. J. Hartel, "Filmfest Offers First Bulgarian Film in U.S.," The Seattle Times (Monday, May 22, 1989), C.9. 
Malinowski, B. "Myth in Primitive Psychology." In Malinowski and the Work of Myth, edited by Ivan Strenski. Princeton: Princeton University Press, cited in Von Hendy, A. The Modern Construction of Myth. Bloomington, IN: Indiana University Press, 2002.

Miladinov, C. and D. Miladinov. Bulgarski Narodni Pesni I Poslovitzi [Bulgarian National Songs and Proverbs], 12, cited in W.R. Morfill, M.A. Slavonic Literature. London: Society for Promoting Christian Knowledge, 1883.

Miles Foley, J. "South Slavic Oral Epic and the Homeric Question." Acta Poetica 26, no. 1-2 (2005), 53-68. Accessed September 21, 2011. http://bit.ly/1pkb50j.

Miles Foley, J. "Tradition and the Collective Talent: Oral Epic, Textual Meaning, and Receptionalist Theory." Cultural Anthropology 1, no. 2 (May 1986), 203-222. Accessed September 25, 2011. bit.ly/1LWjAYY.

Mameluqi [Mameluk]. Directed by Davit Rondeli (1958: Grusia Film/Qartuli Pilmi, 97 min.). http://bit.ly/1SFhr5B

Ménage, V.L. "Devshirme." Encyclopaedia of Islam, Second Edition, Edited by P. Bearman, Th. Bianquis, C.E. Bosworth, E. van Donzel, W.P. Heinrichs. Brill Online. Accessed June 8, 2012.

Mitchell M. Gone With the Wind. New York: Avon Books, 1936.

Postema, A. "My Son I Will Give - My Myth I Will Not: Lineage and Legendary Identity in Donchev's Time of Parting." Balkanista 22 (2009).

Radushev, E."'Peasant Janissaries'?"' Journal of Social History 42, no. 2 (2008). Accessed September 27, 2011. http://bit.ly/1XhJS8Q.

Russell, G.A. "Physicians at the Ottoman Court," Medical History 34, no. 3 (1990): 243-267. Accessed June 8, 2012. 1.usa.gov/1LWibl7.

Taylor, R., Wood, N., Graffy, J., and Iordanova, D. The BFI Companion to Eastern European and Russian Cinema. London: British Film Institute, 2008.

Todorova, M. "Conversion to Islam as a Trope in Bulgarian Historiography, Fiction, and Film." Eurozine (November 4, 2003). Accessed February 24, 2016. http://bit.ly/1QpVjcG.

"Vreme Razdelno," Festival de Cannes official website. Accessed February 24, 2016. bit.ly/1TY7e3S.

Vreme na nasilie [Time of Violence]. Directed by Ludmil Staikov (1988; Boyana Film, 288 min.). bit.ly/1QXt601 and bit.ly/1pqa8Dm;

Zachariadou, E. A. "Janissaries." In The Oxford Dictionary of Byzantium, 3 vols., Edited by Alexander P. Kazhdan et al. New York City: Oxford University Press, 1991. Accessed February 20, 2016. bit.ly/1LYeC8J. 
